Article

\title{
Shanghai's Regenerated Industrial Waterfronts: Urban Lab for Sustainability Transitions?
}

\author{
Harry den Hartog ${ }^{1,2}$ \\ ${ }^{1}$ College of Architecture and Urban Planning, Tongji University, China; E-Mail: harrydenhartog@urbanlanguage.org \\ ${ }^{2}$ Faculty of Architecture and the Built Environment, Delft University of Technology, The Netherlands
}

Submitted: 17 February 2021 | Accepted: 2 June 2021 | Published: 27 July 2021

\begin{abstract}
In China, Shanghai often serves as a place to introduce and try out new ideas. This is certainly the case with experimental urban planning and design solutions and sustainability transitions. This article identifies and evaluates the role of pilot projects and demonstration zones along the Huangpu River. These clusters and zones are supposed to guide the urban regeneration of the former industrial waterfronts and to accelerate innovative development in Shanghai and the wider Yangtze Delta Region. The Huangpu River as a whole is considered an urban lab and a showcase of ecological civilisation policies, with a strong 'people oriented' focus on improving the overall quality and attractiveness of urban life. Following three decades of rapid urban expansion, Shanghai's urban development model is shifting toward one that emphasizes densification and the reuse of existing elements. The motto of Shanghai's latest master plan is "Striving for an Excellent Global City." One of the pathways to realize this expectation is the creation of thematic clusters for creative industries, financial institutes, $\mathrm{Al}$, and technology, media and telecommunication industries. These clusters are high-density investment projects meant to support and accelerate the transformation of Shanghai into a service economy. There are important similarities between these projects in Shanghai and the role of urban labs in theories of sustainability transitions. Drawing on these theories and those of ecological civilization, this article examines how these so-called 'experimental' urban megaprojects along the river contribute to Shanghai's effort to take the lead in developing sustainable urban transitions.
\end{abstract}

\section{Keywords}

ecological civilization; global city; port city; sustainability transitions, urban lab; urban megaprojects; urban regeneration; waterfront transformation

Issue

This article is part of the issue "Planning for Porosity: Exploring Port City Development through the Lens of Boundaries and Flows" edited by Carola Hein (Delft University of Technology, The Netherlands).

(C) 2021 by the author; licensee Cogitatio (Lisbon, Portugal). This article is licensed under a Creative Commons Attribution 4.0 International License (CC BY).

\section{Introduction}

This article examines recent waterfront regeneration projects in Shanghai that are expected to play an experimental and exemplary role. These projects have a strong spatial and socioeconomic impact. By reconnecting the city with the Huangpu River, the waterfronts, after losing their former port role, have once again become the main driver for urban development. Approaching this phenomenon through the lens of sustainability transition theories has not been done before in the Chinese context and fills gaps in the still limited research on recent water- front transformations in Shanghai (den Hartog, 2019, 2020; Li \& Li, 2016; Li \& Zhong, 2020; Yang et al., 2020).

Shanghai's urban development has shifted from an urban expansion model with new towns (den Hartog, 2010) to a model of urban densification and regeneration within red lines that prevent the city from sprawling outward (Shanghai Planning and Land Resource Administration, 2018a). Simultaneously the city is implementing ambitious projects and policies to facilitate an urgently needed shift from quantitative planning toward qualitative planning. The subtitle of Shanghai's latest Master Plan (2017-2035) is: Striving for an Excellent 
Global City (迈向卓越的全球城市; Shanghai Planning and Land Resource Administration, 2018a). According to this plan (abbreviated as Shanghai 2035), the city wants to compete, and possibly surpass, global cities such as New York, London, Singapore, and Tokyo in terms of economy, image, and quality of life. Shanghai 2035 promises to realise "a city of innovation, a cultural city, an ecological city, and a modern socialist metropolis with world influence" by 2035 (Shanghai Planning and Land Resource Administration, 2018a). The urban regeneration of the Huangpu riverfronts plays a key role with no less than 120 kilometres of waterfront transformation intended to eliminate polluting industries, create a continuous open public space (den Hartog, 2019), to make new ecological connections (den Hartog, in press), to reuse industrial heritage (den Hartog, 2020), and to add new landmarks. More than 50 kilometres new waterfronts have been already implemented. This work, accompanied by large real estate clusters, dwarfs other waterfront transformations worldwide.

The research objective is to understand the underlying motivation and effects of emerging pilots and demonstration zones (see Section 2.1) in Shanghai, which are supposed to function as urban labs. The academic objective is to use sustainability transition theories (Section 2.1) in an adjusted way, to analyse and evaluate these urban labs on sustainability aspects, with additional insights from ecological civilisation philosophy (see Section 2.2). The main research questions are: How can an urban lab be identified in the context of Shanghai? How do these pioneering projects contribute to a sustainable transition effort? The following criteria will be examined: adjustability, inclusiveness, functionality, low-carbon impact, and urban vibrancy (see Table 1). Based on this assessment, recommendations for improvement will be made in Section 5 .

Empirical evidence comes from multiple daily-life field observations between 2008 and 2021. Between 2012 and 2021 multiple sections of the waterfronts were analysed intensively in the context of research and design studios with students from Tongji University (7 semesters North Bund, 2 semesters South Bund, 1 semester Yangpu waterfront and Fuxing Island). In 2019 and 2020 more than 300 questionnaires were completed, with student assistance, amongst visitors (tourists, office workers, etc.) on multiple locations along the river. The questions were concerning usability and appreciation of the new public space and buildings. Semi-structured interviews were conducted with two leading real estate analysts, three developers, more than 20 designers and planners involved in relevant projects, three local officials, and more than 10 scholars. Relevant planning documents, media reports and publications were studied, with translation and interpretation assistance available when needed. Preliminary research results have been presented and discussed during workshops and seminars in Shanghai and elsewhere.

\section{Sustainability Transition Theories, Experiments, and Ecological Civilization}

\subsection{Urban Labs and Experiments}

In this article concepts of the sustainability transition discourse frame the empirical analysis and argumentation. These concepts help explain how promising visions of a sustainable future and attractive urban realities are translated on the ground, and how these projects can help shift the urban reality into a more sustainable order. The concept of sustainability in this article follows the Brundtland Report (United Nations, 1987): "Humanity has the ability to make development sustainable to ensure that it meets the needs of the present without compromising the ability of future generations to meet their own needs."

A century ago, scholars from the Chicago School of Sociology approached the city as an urban lab and used the concept of social experimentation (Park, 1929). In contemporary mainly European-centred discourse on sustainable urban transitions, the term urban (living) lab is used for socio-technical experiments with a participatory nature (Steen \& Van Bueren, 2017), usually on a neighbourhood-scale. Urban labs are not necessarily physical, but "represent sites" and "allow stakeholders to design, test and learn from socio-technical innovations in real time" (Wirth et al., 2018, p. 230). Urban labs are tools to find new forms of urban governance to address complex problems; they function as an inspiring sample. They have tended to focus on public spaces such as infrastructures (e.g., NACTO) or greening projects (e.g., Naturvation Atlas).

In the field of sustainability transitions scholars investigate radical shifts toward sustainable socio-technical systems of production and consumption (Evans et al., 2016; Grin et al., 2010; Kivimaa et al., 2017; Sengers et al., 2016; Weiland et al., 2017). Urban labs are usually community-based and follow processes with many steps and turns and not always satisfying results (Karvonen, 2016). Yet, there are successes among these so-called urban transition arenas (Wittmayer et al., 2014).

Three key concepts in this discourse are 'expectations,' 'socio-technical experimentations,' and 'unfolding innovation journeys.' 'Expectations' addresses how stakeholders use tempting visions of a better future in their urban development projects. These visions or "statements about the future" circulate (Van Lente, 2012) and are 'performative,' helping to create a new future reality by coordinating roles and activities amongst actors (Konrad, 2006), and by legitimizing certain investments (Borup et al., 2006). To be effective, these expectations or visions need to be shared by multiple actors (Schot \& Geels, 2008). To translate expectations of creative, innovative, and sustainable urban solutions into realities they are tested and developed in experimental real-life settings: urban labs. Experiments can be seen as key to change. A process of 'socio-technical 
experimentation' by a wide variety of societal stakeholders can transform expectations or visions into reality. Socio-technical experimentation is an open-ended 'unfolding innovation journey' (Van de Ven et al., 1999) or, more specifically, a 'sustainable innovation journey' (Geels et al., 2008), full of uncertainty (Garud et al., 2014). In contrast to experimentation in the natural scienceswhich usually takes place under strictly controlled conditions and is aimed at finding objective certainties - there are multiple external influences possible in an urban lab. Therefore, scholars in the field of sustainability transition studies describe them as 'socio-technical experiments,' which can be defined as: "An inclusive, practice-based and challenge-led initiative, which are designed to promote system innovation through social learning under conditions of uncertainty and ambiguity" (Sengers et al., 2016, p. 162).

How can we identify and evaluate urban labs in Shanghai? In Chinese urban planning and design there are basically three different levels of experimental projects:

First, pilot projects are experiments located in one or several places to be further adjusted and expanded nationwide. They are expected to aid in reformulating relevant policies (e.g., a 'low-carbon pilot'; den Hartog et al., 2018). Second, demonstration projects (or zones) are considered successful experiments that can be replicated and can function as a national or international sample (e.g., Chongming Island as National Ecological Demonstration Zone; den Hartog et al., 2018). Finally, model (文明) projects have been deemed 'excellent' (卓越) social management models that support political principles, e.g., ecological civilisation (see Section 2.2).

These different labels for projects are linked with different financial and governance constructions and can overlap. In Shanghai 2035 the Huangpu River's waterfront as a whole is labelled a "demonstration zone for the development capability of the global city of Shanghai" (Shanghai Planning and Land Resource Administration, $2018 b)$. This is a socio-technical experiment on a municipal level. The waterfront redevelopment is designed and implemented at the district level; each district has founded its own government-owned development company (e.g., West Bund, see Section 3.3). Within these administrative bodies, there are smaller pilot projects for testing specific aspects, such as 'Al Town pilot' and 'art zone pilot' at West Bund (see Section 3.3). All these demonstration zones and pilots have pioneering and guiding roles. They most probably will be awarded with the honourable title 'model project' afterwards. While urban labs, especially in the European context, are usually limited in impact (Scholl \& De Kraker, 2021), the demonstration zones and pilots described in this article have a considerable impact that redefines almost everything, by creating a 'new world.'

\subsection{Ecological Civilization as National Socio-Technical Experiment}

Ecological civilization (Sheng Tai Wen Ming, 生态文明) is a socio-technical experiment that can be defined as a "dynamic equilibrium state where humans and nature interact and function harmoniously" (Frazier et al., 2019, p. 1). According to some scholars, it originated in the discourse on ecological modernization (Zhang et al., 2007). However, it has strong roots in Marxism and some scholars claim that it has the potential to challenge or even replace global capitalism (Gare, 2020). Nevertheless, the concept of ecological civilization has received many sceptical reactions (Hansen \& Liu, 2017; Wang et al., 2014; Wang-Kaeding, 2018). Realizing an ecological civilization means a paradigm shift and drastic societal reform of all aspects of life, including the economic system. Recurring terms in the discourse of urban planning and design in China are 'beautification' and 'harmonization.' Both terms originate from the ecological civilization campaigns and have been promoted by the national government since 2007 (Hansen et al., 2018). Beautification refers to improving the overall urban image, and harmonization means to improve the quality of life and fortune of the society. In Shanghai's urban regeneration efforts beautification and harmonization are apt to mean polishing street life by eliminating whatever does not align with prosperity and modern urban living in the view of local leaders. Informal street markets and old working-class housing are examples of targets for removal. Beautification and harmonization are principles to provide social guidance and reflect strong state control over urban planning and design practices. This State control is also reflected in the new waterfronts of the Huangpu River (den Hartog, 2019). This transition from an industrial civilization to an ecological civilization contains three dimensions that need to be brought into harmony, according to the Communist Party's constitution: the environmental, the economic, and the social. General Secretary Xi continually emphasizes ecological civilization as a more balanced model of economic growth.

\section{Socio-Technical Experimentation: The Huangpu River Waterfront as Stage for Innovation and Ecological Civilization in Shanghai}

\subsection{Shanghai's Frontier-Role}

Shanghai is China's gateway to the world and economic Head of the Dragon, as announced by revolutionary and former statesman Deng Xiaoping in 1992 (Foster et al., 1998). Hence this world port city positions itself as urban laboratory (den Hartog, 2010, 2016). With this 'frontier' role, Shanghai is the stage for many experiments. The former port-related industrial waterfronts have a crucial position in this; they have become a porous interface for new urban development and a way to reconnect city and 
river. City leaders nationwide see Shanghai as an inspiring model with access to new ideas. Many initiatives and trends that started in Shanghai are transplanted elsewhere in China, such as the concept of Xintiandi (den Hartog, 2017).

The origins of Shanghai are inseparable from its location beside the water (Ball, 2017; King, 1911). The strategic deltaic location made Shanghai into an international hub for exchanging goods, finance, and knowledge. The former foreign concessions were zones of exemptions with exclusive rights for a select group-somehow the precursors of current demonstration zones-that accelerated international trade and global connections. It made Shanghai the third-largest banking and finance centre in the world during the 1930s, with the classic Bund as icon. The city's location in the Yangtze River Delta is also a vulnerable one, with flood risk and conflicts between urban, industrial, ecological, and agricultural land use. This location makes Shanghai an excellent place to experiment with new urban planning and design approaches that aim to make the city more sustainable and resilient. The master plan Shanghai 2035 promises this metropolis will play a pioneering role and lead the reform into the era of ecological civilization. The expectation is to become an "environmentfriendly, economically-developed, culturally-diversified and safe liveable city" (Shanghai Planning and Land Resource Administration, 2018a, p. 17). In Shanghai's more detailed master plan for the Huangpu River, the expectation is to build a "world-class waterfront development zone" (世界级滨江发展带). This plan distinguishes three key functions for the river: (1) the river as spatial and functional carrier; (2) the river as the city's public living room with rich human connotation (referring to heritage and identity); and (3) the river as an ecological corridor for a harmonious coexistence between humans and nature, in terms of 'ecological civilization.'

A main 'expectation' as stated in Shanghai 2035 is to become "a more adaptable, resilient eco-city and benchmark for international megacities in terms of green, low-carbon and sustainable development" (Shanghai Planning and Land Resource Administration, 2018a, p. 25). This ambition will be showcased in demonstration zones. According to Shanghai 2035, ecological civilization requires a new balance between top-down and bottom-up governance approaches and an exploration of public-private partnerships and new forms of participation. Citizen participation is mentioned frequently in the final chapter (Shanghai Planning and Land Resource Administration, 2018a). Ecological civilization means a shift to a new planning approach: a process of exploration and new balances between rigid control and flexible adaptation (Chen \& Du, 2018; Xu et al., 2017).

Within the wider context of waterfront regeneration, the various municipal districts of Shanghai developed a dozen large thematic real estate clusters, each of them comparable in size to Canary Wharf in London or Hudson Yards in New York (Figure 1). These clus- ters contain attractive new functional programs, usually related to arts and creativity, but their main share consists of offices, five-star hotels, and exclusive retail. Less than $5 \%$ is (upscale) housing. In the next sections (Sections 3.2-3.4), three prominent zones that contain several of these clusters are described in more detail, chronologically. They have been selected because the municipality has deemed their transformations exemplary and trendsetting.

\subsection{Former Expo 2010}

The expectation that development projects should reconnect the city with the river began in 2002 with the Regional Comprehensive Development Plan for the Huangpu River and preparations for Expo 2010, themed "Better City, Better Life," located on former docklands on both sides of the river (Pudong District and Huangpu District). For this event navy-owned shipyards and about 27,000 housing units were removed. The event accelerated multiple urban projects (Wong, 2010) and made Shanghai "China's pioneer for urban regeneration" (Li \& $\mathrm{Li}, 2016$, p. 342). Across the city it resulted in refurbished facades, green decorations, and the accelerated removal or hiding of everything, especially informal street life and low-income neighbourhoods, that did not fit the desired international image. Expo 2010 was primarily a socio-technical experiment to encourage people to become 'model' citizens (Chen, 2018; Wong, 2010) as part of an early phase of ecological civilization implementation. For example, there were educational campaigns on how to behave in public spaces, for example the tradition of wearing pyjamas outdoors was (temporary) discouraged. Besides being an international business event, Expo 2010 was a moment to experiment with new forms of public-private partnership, loans, and bonds (Chen, 2020). After the event, the innovation journey was interrupted (den Hartog, 2012): Post-event reuse of the area was delayed for 5 years, because suburban development was still more profitable. The well-visited iconic Power Station of Art, China Pavilion, and Mercedes Benz Arena have been exceptions. The Urban Best Practices Area was a showcase with pioneering samples of low-carbon and passive buildings during the expo. The Urban Best Practices Area was meant to become a cultural cluster after the expo ( $\mathrm{Li} \& \mathrm{Li}, 2016$ ), but this was postponed until 2019 because West Bund took over the role, thanks to more successful experimental collaborative governance (see Section 3.3). Currently the Urban Best Practices Area is in the process of revival. Since 2015 the Pudong side of the expo has been filling up with office clusters and malls (Figure 2), instead of needed (affordable) housing.

\subsection{West Bund}

After Expo 2010 the West Bund area started to be redeveloped by a state-owned enterprise with the same 
name, in Xuhui District. Since the mid-19th century, cement and coal deposits, wharfs, and a military airport have dominated the area. This was a pioneering zone during China's industrial development, with new indus- tries and technologies. The 'expectations' were to make the riverside a scenic space for citizens and to establish a pilot International Art Industry Cluster (den Hartog, 2020; Hastings, 2019; Zhou, 2017). The West Bund is

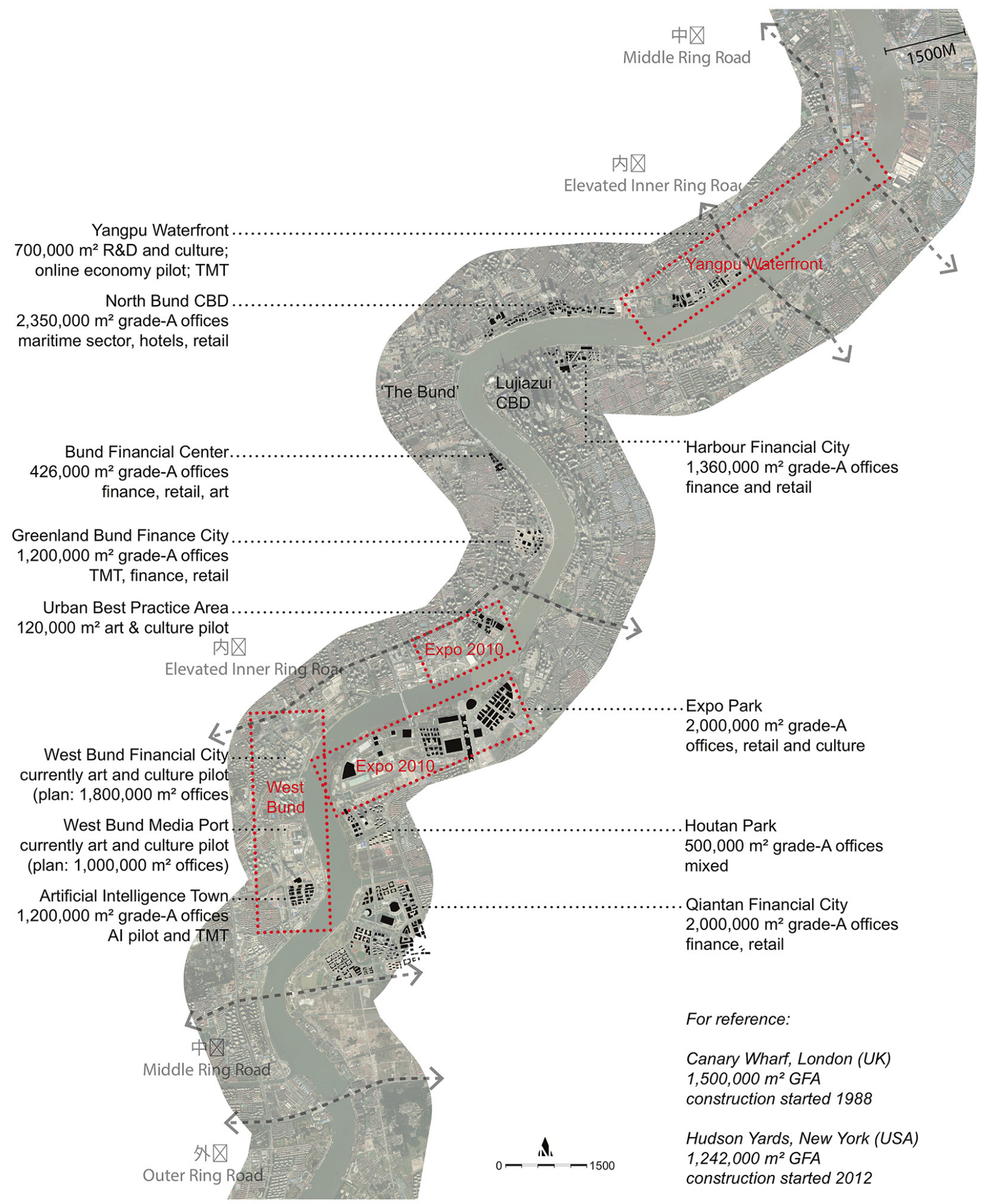

Figure 1. Map with urban megaprojects since 2012 along the central section of the Huangpu River. Source: Image by Harry den Hartog and Jiawei Hu; Satellite photo as underlay by Shanghai-tianditu (2021). 


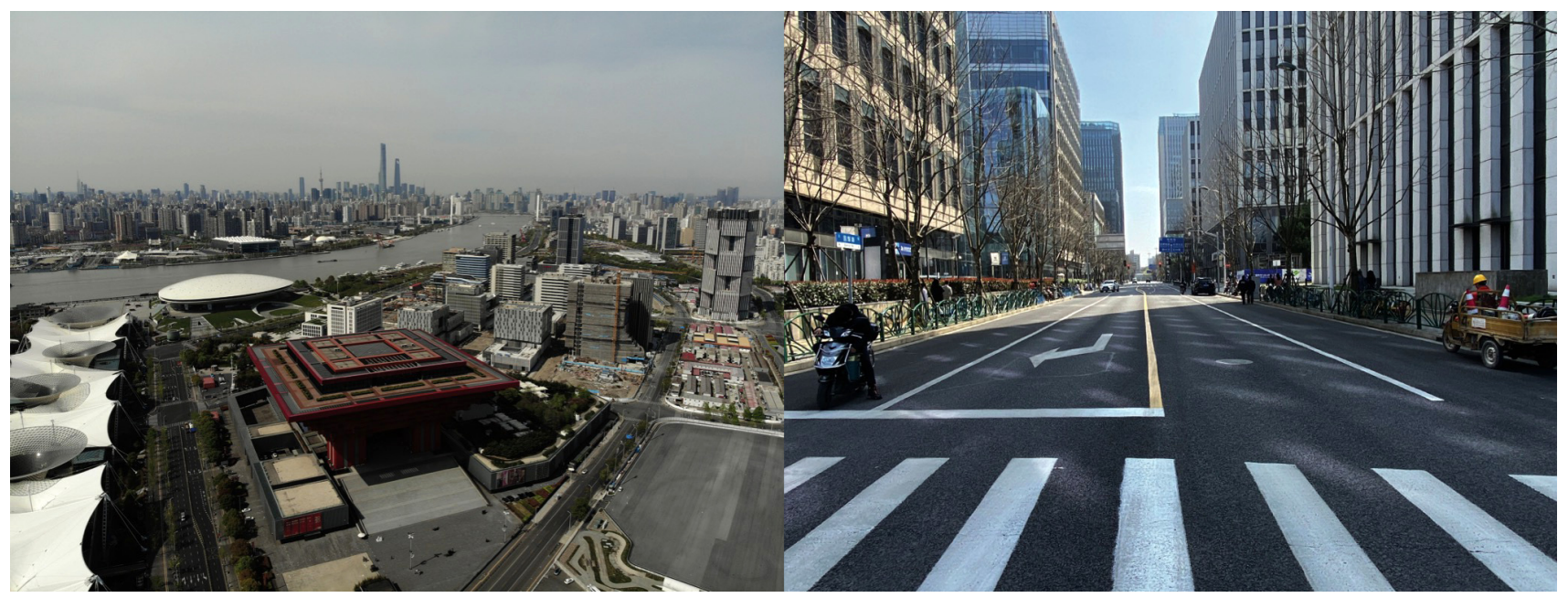

Figure 2. Two pictures of the former expo area filled with grade-A offices around remaining expo-pavilions. Source: Author (Summer 2020).

also a Cultural and Financial Cooperation Pilot Zone that experimented with new forms of "government-led regeneration with market-oriented management and collaborative governance" (Qiu, 2019). Its innovation journey started with the experimental West Bund biennial in 2013 in a former airplane factory. Since 2015 this biennial is renamed in Shanghai Urban Space Art Season, co-organized by West Bund and the municipal Urban Planning Bureau. With a range of onsite events and installations along the waterfront, the aim has been to attract people and (international) investors. West Bund has become a brand. In line with Museum Mile in New York and South Bank in London, a range of museums, galleries, and art events were invited to West Bund. In 2019 even Centre Pompidou opened a branch in the presence of Emmanuel Macron, president of the French Republic. The planning is said to be in accord with ecological civilization by using "culture-oriented, ecobased and technological-innovation-driven" development principles (Shanghai Planning and Land Resource
Administration, 2018a). West Bund is (after the classic Bund) the most intensively used of the new waterfronts in Shanghai. It enjoys experimental exceptions in its freedom of use: Unlike in most other sections visitors are allowed to bring pets and play with kites. Picnic blankets and tents can be spotted on the lawns. There is a large area for electronic dance music events and a skate park. This all has put West Bund on the mental map of a culture-oriented, educated, young, and middleclass section of the population and of international expatriates. In terms of square meters, West Bund is one of the largest art districts in Asia. Its success can be attributed to the proximity of high-end neighbourhoods, tax incentives, and rent-free leases for cultural institutes (Zhou, 2017). In 2013 several buildings were offered for short-term lease to local architecture offices for their emerging practices, and to add a sense of creative entrepreneurial flavour. As soon as the pilot Al Town is completed (Figure 3), these studios could be dismantled. After an innovative journey of branding by creating

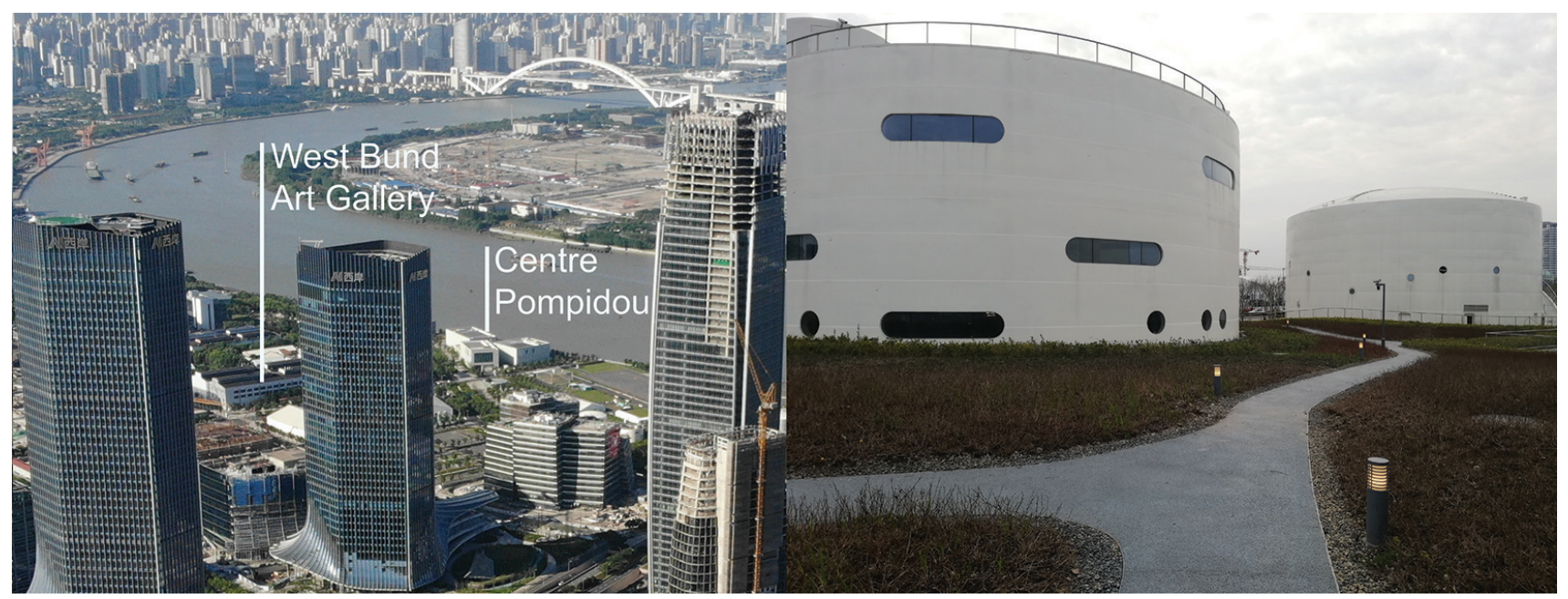

Figure 3. On the left, the AI Town under construction. Between the towers, several art institutes are still visible. On the right, the TANK Shanghai, a pioneering and multifunctional art centre in former oil storage. Source: Author (September 2020). 
a scenic landscape and attracting cultural institutes, the area is gaining a more formal corporate image, aimed at competing for investment on the global stage under the catchy slogan "Art \& Al as engine."

\subsection{Yangpu Waterfront}

Decades before West Bund, Yangpu District's waterfront was a pioneering area for modern Chinese industry, with textiles, shipbuilding, pharmaceuticals, soap making, tobacco, machine manufacturing, public utilities, and more. Together with North Bund (Hongkou District) this waterfront is in the former American Concession, one of the foreign enclaves founded after the Treaty of Nanjing (1842) as a basis for international trade. Late in the last century, the area was run-down, with polluting industries and dilapidated working-class neighbourhoods. Urban regeneration started in 2012 when a textile factory was transformed into the Shanghai Fashion Centre, an outlet mall. Also, at the Yangpu waterfront a Shanghai Urban Space Art Season biennial was organized in 2019 (after the first two editions at West Bund in 2013 and 2015, in 2017 a third edition took place at the East Bund). Today Yangpu promotes its waterfront as a 'World Class Waterfront Development Belt' in an attempt to attract foreign investors. The project is nicknamed "from rustbelt to brainbelt" (Lv \& Wang, 2017). The square meter prices for residential real estate are already up to $€ 13,000$ per square meter (2021). In November 2019, General Secretary Xi visited Shanghai. During his visit he only visited the Yangpu waterfront, which underlines its strategic importance and demonstration role. In the fall of 2021 a key meeting will be held in Shanghai with General Secretary Xi attending, and a large conference venue is under construction at the North Bund waterfront in Hongkou district, not far from the place he visited previously, in a highly visible spot. The original ambitious plans were to make the Yangpu waterfront into an innovation belt with jobs for more than 170,000 people (Lv \& Wang, 2017), but over the past year economic and political realities have changed the innovation journey. Responding to the Covid-19 pandemic the adjusted expectation is to transform the area into a large Online Economy Park (Yang, 2021) based on $5 \mathrm{G}$ technologies and the fast-emerging technology, media and telecommunication sector, which by 2020 already occupied more than $15 \%$ of Shanghai's total office stock. This innovation journey is expected to continue with lower density and much more green space. Today the adjacent plots are still derelict, with several remaining working-class neighbourhoods ready for demolition. The migrant workers who live here seldom use the waterfront spaces, because they have almost no free time. The lack of connectivity between the river and run-down neighbourhoods and the negative connotation in the collective memory (pollution, poverty) of this part of the city make this waterfront still less intensively used than other waterfronts in the city (Figure 4). This trend is expected to be completely reversed over the next five years.

\section{Discussion}

In the international discourse urban labs are supposed to supplement or even replace traditional urban planning approaches, especially following the global economic crash of 2008. Local authorities frequently use urban labs to mask a lack of funding, or to suggest publicprivate partnerships (Karvonen, 2016). The Covid-19 pandemic accelerated the use of urban labs (Honey-Rosés, 2021; Rowe, 2021). In contrast to the grassroots elements in urban labs, the demonstration zones and pilot projects along the Huangpu River are initiated in a top-down manner and are controlled by the local government, usually with substantial international help: investors, engineers, designers and other professionals. Some of these projects experiment with public

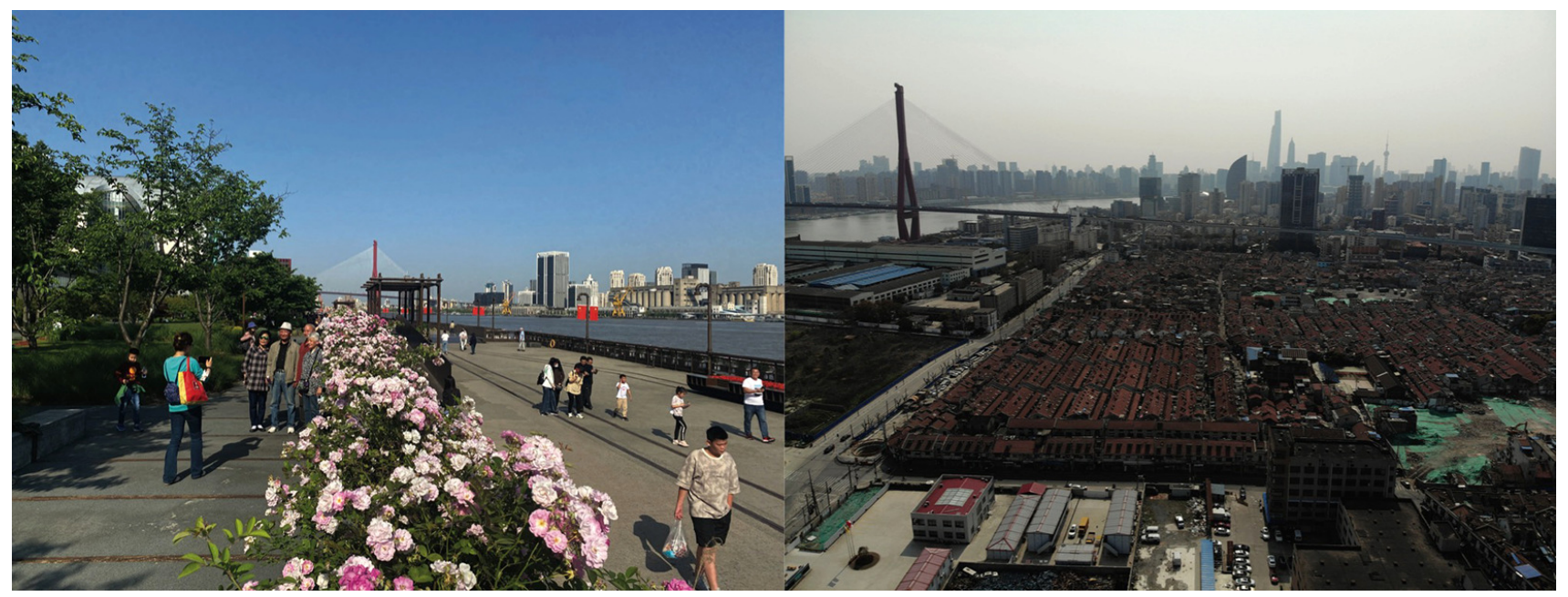

Figure 4. Behind the scenic Yangpu waterfront, working-class neighbourhoods are being demolished. Source: Author (May 2021). 
Table 1. The three cases compared on several aspects.

\begin{tabular}{llll}
\hline & Expo 2010 & West Bund & Yangpu Waterfront \\
\hline $\begin{array}{l}\text { Governing } \\
\text { body: }\end{array}$ & Pudong District and Huangpu District & Xuhui District & Yangpu District \\
Developed by: & $\begin{array}{l}\text { Bureau of Shanghai World Expo } \\
\text { Coordination }\end{array}$ & $\begin{array}{l}\text { Shanghai West Bund } \\
\text { Development Group } \\
\text { (West Bund) }\end{array}$ & $\begin{array}{l}\text { Shanghai Yangpu Binjiang } \\
\text { Investment and } \\
\text { Development Co., Ltd }\end{array}$
\end{tabular}

Size of zone: $\quad 5.28$ square kilometers

Main

expectation: Reconnect city and river

\section{Main \\ 1. First large-scale waterfront}

experiment(s): regeneration experiment;

2. Urban Best Practice Area as showcase for sustainable building techniques, and (post-expo) reuse as Pilot for International Art Industry

Timeline /

2006-2010: event-led urban

innovation

journey:

Inclusiveness:

Removal large amounts of working-class neighborhoods; no new housing available on this site

Functionality: Mostly still desolate, except UBPA and River Mall

Low-carbon Removal of polluting industries; all impact: new constructed buildings received low-carbon labels

Urban Many visitors during Expo in 2010, but vibrancy: almost no visitors afterwards. There is a gradual revival since 2018, but half the lands are still bare. There are preparations to construct a large urban park. Half of the remaining lands are currently used for offices and retail, but these are largely vacant (except the River Mall, the China Pavilion, the Mercedes-Benz Arena, and the Power Station of Art).

\section{9,4 square kilometers}

Art \& Artificial Intelligence as engine; Reconnect city and river

1. Cultural and Financial
Cooperation Pilot Zone
(government-led regeneration
with market-oriented
management and collaborative
governance);
2. Pilot Artificial
Intelligence Town

2010: start waterfront regeneration; West Bund 2013 and SUSAS 2015 (two urban planning and design biennials) acceleration by event-led urban regeneration; Since 2018: start construction Al Town and West Bund Media Port; preparations for West Bund Financial City;

2019: Centre Pompidou opened a branch

Only new high-end housing; public space is very well-used by all kinds of people

\section{Well-functioning}

Removal of polluting industries; all new constructed buildings received low-carbon labels

The West Bund can be seen as experimental 'free zone' with much tolerance for all kind of spontaneous activities. It is a relatively successful area, well visited, and with many art-related events and exhibitions.

\section{2 square kilometers}

Demonstration zone for the construction of a people-oriented city
1. Pilot Online
Economy Park

2010: start waterfront regeneration with transformation of a former textile factory into a fashion outlet;

SUSAS 2017 (urban planning and design biennial) as start large-scale and event-led urban regeneration

Removal of large amounts of working-class neighborhoods, partly replaced by high-end housing complexes

Still rather desolate

Removal of polluting industries; all new constructed buildings received low-carbon labels

During SUSAS 2019 there were temporary many visitors, but much less afterwards. Reuse of the venues is still under consideration. 
participation (Chen, 2018; Shanghai Planning and Land Resource Administration, 2018a), but mainly through incentives (Zhou, 2017).

In fact, these projects are urban megaprojects (Christiaanse et al., 2019; Del Cerro Santamaría, 2013; Hanakata \& Gasco, 2018). Megaprojects can be characterized as "comprehensively planned mixed-use complexes, operated under a single authority and governed by exceptional regulations," usually in public-private partnership (Christiaanse et al., 2019, p. 15). They are intended to function as an accelerating tool in urban regeneration processes aimed to revalorize urban centres. Urban megaprojects-such as Canary Wharf in London or Hudson Yards in New York-are expected to be 'agents of change' (Surico, 2020). Like urban labs, they are powerful drivers of 'urban innovation,' but in the case of Shanghai, the processes are accelerated and amplified. Urban megaprojects have their roots in post-war American urban planning (Altshuler \& Luberoff, 2003), and have been used as a tool by local governments to quickly generate money. With their large-scale and often monumental architecture they "express strong political will, under different political regimes," often supported by neo-liberal motives (Christiaanse et al., 2019, p. 20). Urban megaprojects are the arena where global ambitions meet local values, with socioeconomic gentrifying effects on surrounding neighbourhoods (He, 2007). In Shanghai, they have led to the displacement of large groups of residents and the demolition of characteristic and traditional, but dilapidated, neighbourhoods. In esthetic terms they are "carefully laid-out urban developments" (Christiaanse et al., 2019, p. 15) with a public purpose, used for place-making and identity creation.

Worldwide, urban waterfronts have been used as neoliberal urban policy experiments (Brenner \& Theodore, 2002; lovino, 2018; Sassen, 2014; Zukin, 2020). In Shanghai since the late 1990s, urban planning practice has been increasingly combined with marketdriven developments. This trend in some ways rep- resents a departure from the socialism-with-Chinesecharacteristics approach that emphasized adapting Marxism-Leninism to local Chinese conditions and aimed to improve the quality of life of millions by stimulating the national economy. The emergence of speculative urban megaprojects (Figure 5) along the Huangpu River is characteristic of what Harvey identifies as 'neoliberalism with Chinese characteristics' (Harvey, 2005).

So, what is innovative in these thematic GDP-driven megaprojects along the Huangpu River? At first glance they appear to follow a real estate formula analogous to, for example, Hudson Yards in New York-the largest private real estate development in the US (Sorvino, 2016) that received fierce criticism (Kimmelman, 2019; Wainwright, 2019). The urban megaprojects along the Huangpu River are a mixture of private and state capital, and the spatial and socioeconomic shockwaves they have made in the city and wider region needs research that goes beyond the scope of this article. Nevertheless, compared to the usual urban planning practice in contemporary China, the demonstration zones and pilot projects along the Huangpu indeed introduce new elements, such as walkable and car-free environments, functional mixing, and the inventive use of underground spaces. Innovative in the context of Shanghai and China is also the large amount of green and public space aimed at recreational use. Less than a decade ago there were hardly any walking or cycling paths, and the concept of a leisure society is still unknown. Moreover, pilot projects with high-end art, Al industries, and an online economy are unique in China and far beyond. These urban megaprojects can compete in appeal with those in other world cities, and are perhaps even better designed. Most of the buildings and public spaces are actually designed with the help of leading international architects, including David Chipperfield Architects, Foster + Partners, Heatherwick Studio, Kengo Kuma, KPF, OMA, Sanaa, Sou Fujimoto, and also many emerging local talents such as Atelier Deshaus and OPEN Architecture.

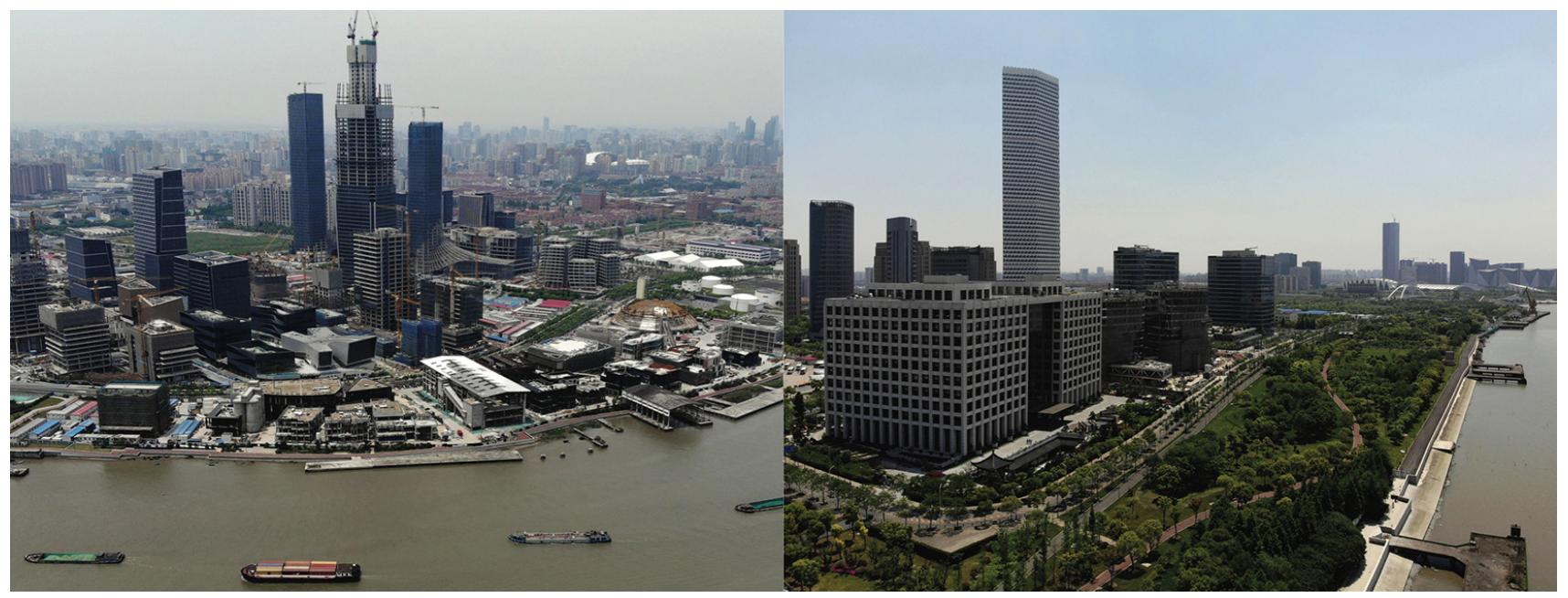

Figure 5. Emerging urban megaprojects Al Town (left picture) and Houtan (right picture), with super-tall landmarks. Source: Author (March 2021). 
With the exception of the International Art Industry pilot at West Bund, as described in Section 3, other megaprojects along the Huangpu experience difficulties attracting office tenants, as well as users of the eyepleasing public spaces. From field surveys with students a range of shortcomings came to light. Most of the new waterfront spaces lack facilities and have functional limitations (Figure 6; den Hartog, 2019). Local governmentrelated institutions and companies have been relocated here, while (international) art institutes have been attracted by incentives (Zhou, 2017). Although most museums are intensively used, most office areas are still under-occupied. From field surveys and conversations with real estate specialists, it became clear that most of the offices are merely used for speculative investment, with a third of the offices taken up by foreign investors. According to leading experts from Cushman \& Wakefield, the average vacancy rate in Shanghai is about $20 \%$, though in some waterfront projects it is much higher; other office locations such as Hongqiao Hub are preferred due to lower pricing and better connectivity (personal communication, 29 October 2020; see also Hatton, 2020). From personal conversations with multiple users of the buildings, it became evident that the actual vacancy rate is far higher than this average. More than a few buildings are completely empty several years after completion, and were empty even before the start of the Covid-19 pandemic and the US-China trade dispute (Hammond, 2019). There is uncertainty about the actual need for these office spaces. Exemplary is the well-known Shanghai Tower, the world's third tallest and presented as sustainable (it has a LEED Platinum label), but more than a third of its floors have been empty since 2016 (personal communication with users, September 2021)! Such projects provide scenic backgrounds for taking photos, analogous with the crowded classic Bund, where swarms of tourists take selfies with the skyline as background (preferably without freight ships). The new waterfronts mainly facilitate a new white-collar (upper) middle class and tourists. Interviews by students with users on site during the autumn of 2020 revealed that most users are occasional visitors living at least half an hour away by car or public transport. The new waterfronts are still relatively unknown to local citizens, even though local authorities launched multiple publicity campaigns and events along the water, such as marathons and music events. Words such as art, creativity, and innovation are happily used for branding with specific target groups. 'Culture' has become a market currency (Zhou, 2017). While the future of West Bund is not yet sure, the main venue of Shanghai Urban Space Art Season 2017 at East Bund will be reused as a museum for the Chinese Communist Party. Former venues of the Shanghai Urban Space Art Season in 2019 are still empty, with "reuse under consideration" (Personal communication with key stakeholder, 22 May 2021).

In short, the megaprojects along the Huangpu River appear to be primarily oriented to support the desired image of a global city, and to stimulate the economy with investment and tourism. They provide an excellent illustration of 'neoliberalism with Chinese characteristics' (Harvey, 2005). Usability for citizens in daily life seems secondary (den Hartog, 2019; Li \& Zhong, 2020). Ecological values will be studied further in another article by this author (den Hartog, in press). Perhaps the inspection of the Yangpu waterfront last year by the General Secretary might change this unsustainable tendency, since he emphasized serving the people (为人民服务) and taking a people-oriented (以人为本) approach, two recurring terms associated with ecological civilization.

Urban planning and design in China is characterized by impressively large investments in advance for public infrastructures (including public space and cultural facilities). This helps to create an attractive environment for investors and citizens, which are expected to come eventually, even after years of vacancy (Shepard, 2015). In the People's Republic, all urban land is owned by the state. Selling land-use rights is a main source of income for local

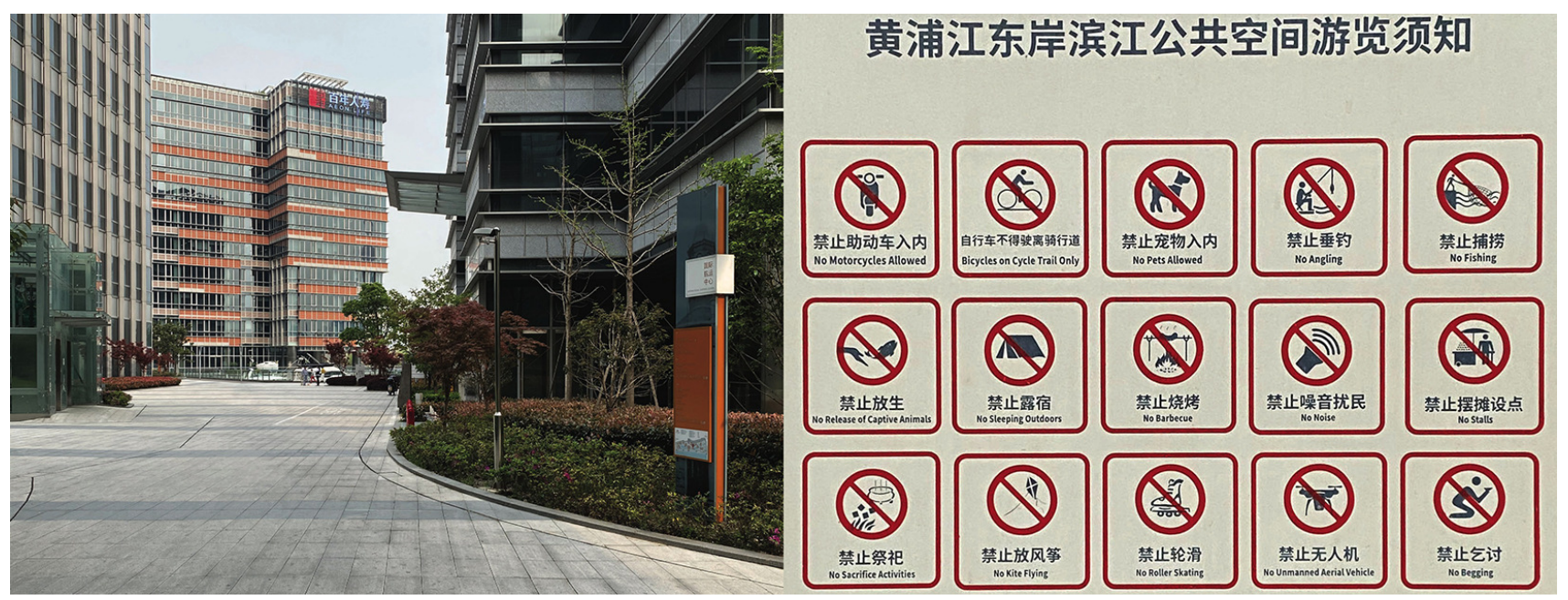

Figure 6. Multiple vacant offices, here at North Bund, and limitations in the use of public space, here on former Expo 2010 site. Source: Author (Autumn 2019). 
authorities. Shanghai's regenerated waterfronts are thus an investment vehicle for the city. Simultaneously, the new skyline and green décor adds to the desired 'excellent global' image and attracts tourists. This speculative approach has strong analogies with the functioning and image of the classic Bund with its line-up of bank buildings, the starting point for international trade and foundation of the former concessions (Figure 7). These 'new bunds' are like enclaves with different regimes, aimed at trade and investment. Though their boundaries are physically porous, they create new socioeconomic limitations and have strong gentrifying effects on the surrounding city. After decades of socioeconomic decline, China is using its current period of prosperity not only to catch up, but also to invest in its future by creating overcapacity in square meters of office space, museum space, and so forth. As long as the percentage of workers in the service economy in Shanghai is significantly lower than in competing global cities such as London and New York, there will be interest in building more offices, even when there is little demand for them yet. From this point of view, the creation of oversupply during economic prosperity can be explained as sustainable development. Still, this causes friction with the before-mentioned common definition of sustainability (United Nations, 1987), especially since unquestionably it is not inclusive to replace affordable working-class neighbourhoods with exclusive (and mainly empty) real estate.

What makes these projects sustainable? Besides the removal of polluting industries and building low-carbon buildings in return, the projects are pedestrian-oriented. However, only half of the real estate clusters are within walking distance of a metro station. All buildings meet the National Green Building standard; in many cases even international labels such as LEED are obtained, although the labels are questionable here (den Hartog et al., 2018). Yet, as described in Sections 3 and 4 the motivation behind the projects is primarily economically based, but goes along with an intention to improve the image and quality of life. Environmental concerns are taken into consideration, but are not yet prioritized (den Hartog, in press). The megaprojects focused on finance and innovation or tourism and creative industries are expected to make Shanghai into an excellent global city. According to Sassen (1991) a global city is a 'post-industrial production site' characterized by strategic transnational networks that support significant specialized financial and producer services that keep the globalized economy running (Sassen, 1991). Shanghai certainly excels in terms of city branding through architecture and new public waterfronts of high quality. In contrast to small-scale urban (living) labs, the

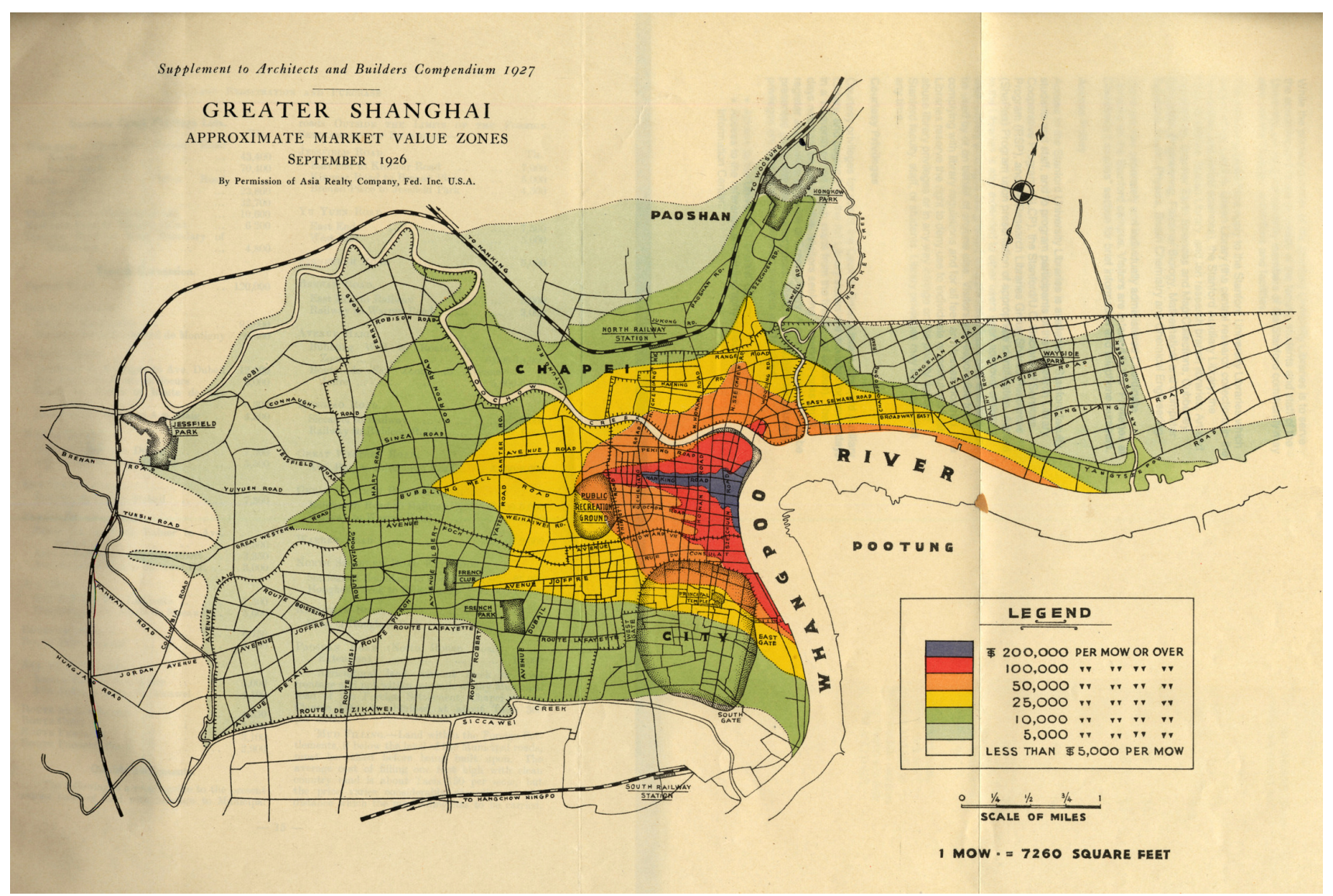

Figure 7. During the period of foreign concessions, Shanghai's Nanjing Road area and Bund (both in purple) became the new heart of the city, and housed multiple headquarters, foreign banks, and shipping companies. The former foreign concessions used to be closed to local Chinese citizens. Source: Brooke and Davis (1927). 
large-scale pilot and demonstration projects along the Huangpu River do have an impact: They finance the city, enable the relocation of polluting industries, upgrade the overall city image, and add desirable qualities through place-making and greenery.

Should these megaprojects be considered urban labs as discussed in sustainability transition theories? The quantity and quality of their public space and real estate along the waterfront is impressive. Their 'statements about the future' are robust and shared by multiple actors (Schot \& Geels, 2008; Van Lente, 2012), although citizens are excluded (den Hartog, 2019; Li \& Zhong, 2020). The projects are also practice-based and challenge-led (Sengers et al., 2016) in their approach. Governance processes in Shanghai involve a complex interplay of multiple groups or departments (Miao \& Lang, 2014; Zhou, 2017), and interplay between top-down authority and bottom-up agency (Li \& Zhong, 2020), but they operate as one entity that can overrule all non-governmental stakeholders. The local government has absolute ownership and mandate over all urban lands. This makes it necessary to redefine the urban lab as concept in the Chinese context. The term 'lab' suggests that failure is possible, while the terms 'demonstration zone' and 'pilot project' point to an excellent 'expectation' that excludes failure. Thus, the described projects are not as intended to be open-ended (Van de Ven et al., 1999) as urban labs are in the international (mainly European-centred) discourse. System innovation is a controlled process in Shanghai. This means that social learning factors including feedback from end-users have generally been excluded, although some initial steps have been taken to consider that feedback (Li \& Zhong, 2020; Shanghai Planning and Land Resource Administration, 2018a). Urban labs are tools to find new forms of urban governance. Experimentation has helped China introduce innovative policies, and local officials are encouraged to experiment to find innovative solutions and to give feedback to help adjust national policy formulations (Miao \& Lang, 2014). This has even created opportunities to experiment with 'exemptions' allowing marketization in a planned economy (Zhou, 2017). The government especially encourages innovation clusters as incubators for new industries and as a source of change. Yet, due to the urge to catch-up socioeconomic experimentation in China often resembles making something quickly, followed by adjustments during implementation-i.e., improvising. Urban planning and design is usually an innovation journey based on collecting best practices for inspiration and improving or adjusting them as needed (den Hartog, 2010). This offers unlimited flexibility, especially since labour costs in Shanghai are still relatively low. Compared to urban labs, the described projects in Shanghai are characterised by large-scale functional programming without direct relationship to their context. They are built in a short time, without a clear time horizon or plans for (re)use. As enclaves of 'neoliberalism with Chinese characteristics' (Harvey, 2005) the projects are indeed "niches where disruptive innovation takes place" (Loorbach, 2014).

\section{Conclusion and Recommendations}

In summary, approaching the demonstration zones and pilots through the lens of urban transition theories is helpful to identify bottlenecks, but the terms 'demonstration zone' and 'pilot' are indeed more suitable than 'urban lab' based on their emphasis on image-building and steering roles. Differences in governance structure, socioeconomic context, scale, stakeholders, and impact, make it necessary to explain the described cases through the lens of ecological civilization philosophy. Adjustment of perspective is needed to be helpful in developing recommendations for improvements in governance and possible new directions. If ecological civilisation claims to be an alternative to global capitalism (Gare, 2020) and expects to bring harmony by balancing environmental, economic, and social dimensions, than the megaprojects along the waterfronts are for the moment not a convincing demonstration of this potential. How can we find a way to adjust or improve the effects of the demonstration zones and pilot projects along the Huangpu? Based on the discussion above, some recommendations can be made.

A first recommendation is to add sufficient (affordable) housing, including new housing typologies aimed at more diversity of households, including young talents. The locations discussed offer sufficient space for a great deal of housing. A returning keyword in the discourse on ecological civilization is 'high quality of life.' Shanghai wants to excel as a global city, attract foreign investment, and offer a comfortable living environment. But in practice, this comfortable living environment is only accessible for a selective upper (middle) class (Chen \& Sun, 2007). Such exclusiveness does not add to urban vibrancy. According to interviewed real estate analysts, inclusiveness and diversity in population and housing will result in more attractive urban street life, which is crucial to attract foreign companies and investment (personal communication, 29 October 2020).

A second recommendation is to fill vacant floors (temporarily) with $\mathrm{SOHO}$ units (small-office-home-office) and start-up companies. This will add 24-hour urban vibrancy and diversity. This is especially recommended for the former Expo 2010 site. The scale of the current oversupply dwarfs the market failure of Canary Wharf in London in the 1990s (when $60 \%$ of the offices were vacant, followed by a revival a decade later). The new mode of working due to the pandemic makes vacant offices even less likely to be used soon, as confirmed by multiple real estate experts worldwide. Yangpu waterfront is already anticipating this.

This leads to a third recommendation that a useroriented approach is needed in advance, along with a more flexible and open setup able to absorb unexpected shocks (e.g., trade disputes and pandemics); in other 
words, what is needed is resilience. The creation of a buffer is only sustainable if oversupply can be changed into other usages easily, instead of being redundant. This fits with the mentioned principles of ecological civilisation and also with before mentioned concept of sustainability (United Nations, 1987).

The formerly inaccessible waterfronts have been made more porous and accessible to the public, but still there are limitations in accessibility. Meanwhile, the thematic corporate and cultural clusters form socioeconomic enclaves, due to their exclusive character and the mode of targeting specific users. A fourth recommendation is improving connectivity with surrounding neighbourhoods by increasing porosity in all cases described (people-oriented for all people). Additionally, lessons should be learned from experiences in other worldport cities, especially New York, where large-scale urban development has been counterbalanced by opportunities for small-scale and grassroots developments resulting in urban vibrancy (Jacobs, 1961).

A fifth recommendation is to nurture the promise of ecological civilisation regarding the reintroduction and stimulation of grassroots elements in governance (Li \& Zhong, 2020; Miao \& Lang, 2014). This is also explicitly included in Shanghai 2035 (Shanghai Planning and Land Resource Administration, 2018a). More creative, inclusive, and participatory forms of experimentation are needed. For this purpose, studying lessons from urban (living) labs in other countries with consideration of potential scalability is recommended. Vice versa other cities could study cases in Shanghai, since there are promising outcomes in terms of quality, scale, and effectiveness. Nevertheless, tailor-made approaches and adjustments are needed in other contexts because of differences in preferences, appreciation, and governance. Shanghai is in a different phase of socioeconomic development than established global cities and needs to deal with a different audience, with other priorities and expectations.

China's unique socioeconomic journey toward an ecological civilization and sustainability transition will certainly make an impact in Shanghai, elsewhere in China, and even far beyond, such as in the Global South. Ideally, more inclusive experiments will follow and transform Shanghai into a world-leading lab for sustainable transition and innovation.

This study has limitations. Not all stakeholders were able to meet or speak with the author. There might be differences in definition or interpretation, although translation was continually available. The complexity, scale, and impact of the subject offer options for further research on multiple aspects. The timeframe of the current Shanghai Master Plan spans until 2035. Many unforeseen changes could happen in that time. This journey, filled with uncertainty, will continue.

\section{Acknowledgments}

Thanks to all interviewees willing to share their experiences and insight to support this research and thanks to the students of my research and design studios at Tongji University, College of Architecture and Urban Planning, who helped to collect basic data and helped with completing questionnaires on site. Thanks to Leijie Su for helping me with translation during interviews, and to Xiyan Yang and Jiawei Hu for collecting, translating and interpreting documents and data. The author received no financial support for the research, authorship, and/or publication of this article.

\section{Conflict of Interests}

The author declares no conflict of interests.

\section{References}

Altshuler, A., \& Luberoff, D. (2003). Mega-projects: The changing politics of urban public investment. Lincoln Institute. https://www.lincolninst.edu/publications/ articles/changing-politics-urban-mega-projects

Ball, P. (2017). The water kingdom: A secret history of China. University of Chicago Press.

Borup, M., Brown, N., Konrad, K., \& Van Lente, H. (2006). The sociology of expectations in science and technology. Technology Analysis \& Strategic Management, 18(3/4), 285-298.

Brenner, N., \& Theodore, N. (2002). Cities and the geographies of 'actually existing neoliberalism,' Antipode, 34(3), 349-379.

Brooke, J. T. W., \& Davis, R. W. (1927). The China architects and builders compendium. North China Daily News \& Herald.

Chen, L., \& Du, F. (2018). Practice and exploration on Shanghai territory spatial planning from the perspective of ecological civilization. Journal of Land and Spatial Planning. https://doi.org/10.11982/ j.supr.20190401

Chen, X., \& Sun, J. (2007). Untangling a global-local nexus: Sorting out residential sorting in Shanghai. Environment and Planning, 10, 2324-2345.

Chen, Y. (2018). Not just "Better City, Better Life": Creating sustainable urban legacy beyond World Expo 2010 in Shanghai. In Bureau international des expositions bulletin (pp. 114-133). BIE. https://www.bieparis.org/site/en/publications/annual-bulletin

Chen, Y. (2020). Financialising urban redevelopment: Transforming Shanghai's waterfront. Land Use Policy. https://doi.org/10.1016/j.landusepol.2020.105126

Christiaanse, K., Hanakata, N., \& Gasco, A. (2019). The grand projet: Understanding the making and impact of urban megaprojects. Nai010.

Del Cerro Santamaría, G. (2013). Urban megaprojects: A worldwide view (Vol. 13). Emerald. 
den Hartog, H. (2010). Shanghai as urban experiment. In H. den Hartog (Ed.), Shanghai New Towns: Searching for community and identity in a sprawling metropolis (pp. 63-81). 010 Publishers.

den Hartog, H. (2012). Shanghai na de Expo: Better city, better life? [Video]. https://www.archined.nl/2012/ 11/architv-reportage-shanghai-na-de-expo-bettercity-better-lifeshanghai-na-de-expo-better-citybetter-life

den Hartog, H. (2016). China, Urban Lab: nut en noodzaak van Experimenteren [China, urban lab: The usefulness and necessity for experimentation]. Rooilijn, 49(4), 282-291.

den Hartog, H. (2017). Searching for a new identity in a rapidly transforming urban landscape. Built Heritage, 1, 41-50. https://doi.org/10.1186/BF03545662

den Hartog, H. (2019). Re-defining the appreciation and usability of urban watersides in the urban center and peri-urban fringes of Shanghai. European Journal of Creative Practices in Cities and Landscapes, 2(1), 37-64.

den Hartog, H. (2020). How can the massive reuse of Shanghai's former industrial waterfronts become more than a city branding strategy and reconnect the city with the water? In T. Mager (Ed.), Water heritage: Global perspectives for sustainable development (pp. 291-306). Bureau of Cultural Heritage, Ministry of Culture of Taiwan.

den Hartog, H. (in press). Engineering an ecologicalcivilization along Shanghai's main waterfront and coastline: Evaluating ongoing efforts to construct an urban eco-network. Frontiers in Environmental Science.

den Hartog, H., Sengers, F., Xu, Y., Xie, L., Jiang, P., \& De Jong, M. (2018). Low-carbon promises and realities: Lessons from three socio-technical experiments in Shanghai. Journal of Cleaner Production, 181, 692-702.

Evans, J., Berkhout, F., Karvonen, A., \& Raven, R. (2016). The experimental city: New modes and prospects of urban transformation. In J. Evans, A. Karvonen, \& R. Raven (Eds.), The experimental city (pp. 1-12). Routledge.

Foster, H. D., Lai, D. C., \& Zhou, N. (1998). The dragon's head: Shanghai, China's emerging megacity. Western Geographical Press.

Frazier, A. E., Bryan, B. A., \& Buyantuev, A. (2019). Ecological civilization: Perspectives from landscape ecology and landscape sustainability science. Landscape Ecology, 34, 1-8.

Gare, A. (2020). The eco-socialist roots of ecological civilization. Capitalism Nature Socialism, 1, 37-55.

Garud, R., Gehman, J., \& Giuliani, A. P. (2014). Contextualizing entrepreneurial innovation: A narrative perspective. Research Policy, 43, 1177-1188.

Geels, F., Hekkert, M., \& Jacobsson, S. (2008). The dynamics of sustainable innovation journeys. Technology Analysis \& Strategic Management, 20(5), 521-536.
Grin, J., Rotmans, J., \& Schot, J. (2010). Transitions to sustainable development: New directions in the study of long-term transformative change. Routledge.

Hammond, G. (2019, October 17). China's office market sees highest vacancy rate in a decade. Financial Times. https://www.ft.com/content/edce2600f0a0-11e9-ad1e-4367d8281195

Hanakata, N. C., \& Gasco, A. (2018). The Grand Projet politics of an urban age: Urban megaprojects in Asia and Europe. Palgrave Communications, 4, Article 86. https://doi.org/10.1057/s41599-018-0141-5

Hansen, M. H., Li, H., \& Svarverud, R. (2018). Ecological civilization: Interpreting the Chinese past, projecting the global future. Global Environmental Change, 53, 195-203.

Hansen, M. H., \& Liu, Z. (2017). Air pollution and grassroots echoes of "Ecological Civilization" in rural China. Cambridge University Press.

Harvey, D. (2005). A brief history of neoliberalism. Oxford University Press.

Hastings, S. (2019, November 10). 'The scene has exploded': China gets set to be leading global centre for art. The Guardian. https://www.theguardian. com/world/2019/nov/10/shanghai-art-fair-chinaset-to-be-global-art-centre

Hatton, J. (2020). Shanghai office rents slide as vacancy hits ten year high. Mingtiandi. https://www. mingtiandi.com/real-estate/china-real-estateresearch-policy/shanghai-office-rents-slide-asvacancy-climbs

He, S. (2007). State-sponsored gentrification under market transition: The case of Shanghai. Urban Affairs Review, 43(2), 171-198.

Honey-Rosés, J. (2021, March 18). The case for formal urban experiments. The Conversation. https:// theconversation.com/is-temporary-the-newpermanent-covid-street-experiments-open-oureyes-to-creating-better-cities-156591

lovino, G. (2018). Urban regeneration strategies in waterfront areas: An interpretative framework. Journal of Research and Didactics in Geography, 1, 61-75.

Jacobs, J. (1961). The death and life of great American cities. Random House.

Karvonen, A. (2016). Andrew Karvonen on experiments and urban living labs. NordRegio. https:// nordregio.org/nordregio-magazine/issues/peopleand-cities/andrew-karvonen-on-experiments-andurban-living-labs

Kimmelman, M. (2019, March 14). Hudson Yards is Manhattan's biggest, newest, slickest gated community. Is this the neighborhood New York deserves? The New York Times. https://www.nytimes.com/ interactive/2019/03/14/arts/design/hudson-yardsnyc.html

King, F. H. (1911). Farmers of forty centuries: Or, permanent agriculture in China, Korea and Japan. Democrat Printing Co.

Kivimaa, P., Hildén, M., Huitema, D., Jordan, A., \& Newig, 
J. (2017). Experiments in climate governance: A systematic review of research on energy and built environment transitions. Journal of Cleaner Production, 169, 17-29.

Konrad, K. (2006). The social dynamics of expectations: The interaction of collective and actor-specific expectations on electronic commerce and interactive television. Technology Analysis \& Strategic Management, 18(3/4), 429-444.

Li, L., \& Li, Z. (2016). Urban waterfront regeneration in the context of Shanghai world exposition. In W. Ding, Y. Hu, \& P. Guo (Eds.), Urban morphology and the resilient city: Proceedings of the 23rd ISUF (pp. 336-343). Digital Media Press.

Li, Y., \& Zhong, X. (2020). 'For the people' without 'by the people': People and plans in Shanghai's waterfront development. International Journal of Urban and Regional Research. https://doi.org/ 10.1111/1468-2427.12964

Loorbach, D. (2014). To transition! Governance panarchy in the new transformation. Erasmus University.

Lv, K., \& Wang, I. (2017). Yangpu waterfront: From rustbelt to brainbelt. Global Infrastructure Initiative. https://www.globalinfrastructureinitiative.com/ article/yangpu-waterfront-rustbelt-brainbelt

Miao, B., \& Lang, G. (2014). A tale of two eco-cities: Experimentation under hierarchy in Shanghai and Tianjin. Urban Policy and Research, 33(2), 247-263.

Park, R. E. (1929). The city as a social laboratory. In T. V. Smith \& L. D. White (Eds.), Chicago: An experiment in social science research (pp. 1-19). University of Chicago Press.

Qiu, Y. (2019). Stakeholders and partnership in urban regeneration: The case of Shanghai West Bund [Master's thesis, Colombia University]. https:// academiccommons.columbia.edu/doi/10.7916/d8etbb-3372

Rowe, H. (2021). The case for formal urban experiments. The CityFix. https://thecityfix.com/blog/thecase-for-formal-urban-experiments

Sassen, S. (1991). The global city: New York, London, Tokyo. Princeton University Press.

Sassen, S. (2014). Expulsions, brutality and complexity in the global economy. The Belknap Press of Harvard University.

Scholl, C., \& De Kraker, J. (2021). The practice of urban experimentation in Dutch city labs. Urban Planning, 6(1), 161-170.

Schot, J., \& Geels, F. (2008). Strategic niche management and sustainable innovation journeys: Theory, findings, research agenda and policy. Technology Analysis \& Strategic Management, 20(5), 537-554.

Sengers, F., Wieczorek, A. J., \& Raven, R. (2016). Experimenting for sustainability transitions: A systematic literature review. Technological Forecasting and Social Change, 145, 153-164.

Shanghai-tianditu. (2021). Map. http://shanghai. tianditu.gov.cn/map/share/lsyx.html
Shanghai Planning and Land Resource Administration. (2018a). Shanghai Master Plan 2017-2035. https:// ghzyj.sh.gov.cn/ghjh/20200110/0032-811864.html

Shanghai Planning and Land Resource Administration. (2018b). Striving for a world-class waterfront area: Shanghai Huangpu River and Suzhou River planning. http://www.shjx.org.cn/article-17574.aspx

Shepard, W. (2015). Ghost cities of China. Zed Books.

Sorvino, C. (2016, May 31). Hudson Yards, America's largest private real estate development, opens first building. Forbes. https://www.forbes.com/sites/ chloesorvino/2016/05/31/hudson-yards-americaslargest-private-real-estate-development-opensfirst-building/?sh=4242034a5f30

Steen, K., \& Van Bueren, E. (2017). The defining characteristics of urban living labs. Technology Innovation Management Review, 7(7), 21-33.

Surico, J. (2020). Understanding mega-infrastructure in 2020: Hudson Yards as a case study. Medium. https://medium.com/@jsurico15/understandingmega-infrastructure-in-2020-hudson-yards-as-acase-study-184378016592

United Nations. (1987). Our common future. https:// sustainabledevelopment.un.org/content/ documents/5987our-common-future.pdf

Van de Ven, A., Polley, D., Garud, R., \& Venkataraman, S. (1999). The innovation journey. Oxford University Press.

Van Lente, H. (2012). Navigating foresight in a sea of expectations: Lessons from the sociology of expectations. Technology Analysis \& Strategic Management, 24(8), 769-782.

Wainwright, O. (2019, April 9). Horror on the Hudson: New York's \$25bn architectural fiasco. The Guardian. https://www.theguardian.com/artanddesign/2019/ apr/09/hudson-yards-new-york-25bn-architecturalfiasco

Wang, Z., He, H., \& Fan, M. (2014). The ecological civilization debate in China: The role of ecological Marxism and constructive postmodernism: Beyond the predicament of legis/ation. Monthly Review. http://monthlyreview.org/2014/11/01/theecological-civilization-debate-in-china

Wang-Kaeding, H. (2018). What does Xi Jinping's new phrase 'ecological civilization' mean? An investigation of the phrase is pressing. The Diplomat. https://thediplomat.com/2018/03/what-does-xijinpings-new-phrase-ecological-civilization-mean

Weiland, S., Bleicher, A., Polzin, C., Rauschmayer, F., \& Rode, J. (2017). The nature of experiments for sustainability transformations: A search for common ground. Journal of Cleaner Production, 169, 30-38.

Wirth, T., Von Fuenfschilling, F., Frantzeskaki, N., \& Coenen, L. (2018). Impacts of urban living labs on sustainability transitions: Mechanisms and strategies for systemic change through experimentation. European Planning Studies, 27(2), 229-257. https://doi.org/ 10.1080/09654313.2018.1504895 
Wittmayer, J. M., Roorda, C., \& Steenbergen, F. v. (2014). Governing urban sustainability transitions: Inspiring examples. DRIFT.

Wong, R. (2010). Upgrading the city quality of Shanghai making use of the 2010 World Expo opportunity. http://www.kenken.go.jp/japanese/contents/cib/ w101/pdf/mtg/1005salford/session01.pdf

Xu, Y., Liao, Z., \& Liu, S. (2017). New concept, new goals, and new model: Reflection and exploration on the transformation of Shanghai megacity. City Planning Review, 41(8), 21-30.

Yang, C., Han, Q., \& Geng, H. (2020). Urban vitality analysis of Battery Park City New York and waterfront qual- ity raising measures along Huangpu River Shanghai. City Design.

Yang, J. (2021). Online economy park for Yangpu waterfront. Shine. https://www.shine.cn/news/metro/ 2101042688

Zhang, L., Mol, P. J. A., \& Sonnenfeld, A. D. (2007). The interpretation of ecological modernization in China. Environmental Politics, 16, 659-668.

Zhou, Y. (2017). Urban loopholes. Creative alliances of spatial production in Shanghai's city center. Birkhäuser.

Zukin, S. (2020). The innovation complex. Oxford Scholarship Online.

\section{About the Author}

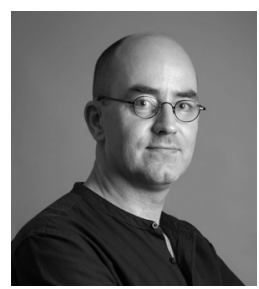

Harry den Hartog is an Urban Designer, Researcher, and Critic. He was trained in the Netherlands and is currently based in Shanghai since 2008 where he runs his studio Urban Language (www.urbanlanguage.org). Since 2012 den Hartog became a faculty member at Tongji University in Shanghai, College of Architecture and Urban Planning. During the years he did a lot of research on new town developments, urban-rural transitions, and waterfront transformations. 